\title{
FEATURE Bridging the divide: Uniting rural and urban landscapes for conservation
}

\author{
Clare Lindahl
}

$\mathrm{T}$ he management of soil and water has been accelerated by agricultural and urban dynamics, and the potential to utilize policy, planning, and partnerships to unite rural and urban landscapes for the betterment of our natural resources and communities is being realized now more than ever. One arena in which these collaborations have proven to be effective is watershed planning. As a leader in multidisciplinary research and an organization that fosters communication among stakeholders, the Soil and Water Conservation Society (SWCS) has had several recent opportunities to advance watershed planning goals through policy initiatives, events, and publications. During the upcoming 2019 SWCS International Annual Conference in Pittsburgh, Pennsylvania, the Society will bring these partnerships, as well as other successes and challenges of rural and urban conservation endeavors, to the forefront of the conversation.

Watershed planning is a conservation effort that has been bridging divides and forging new relationships for a very long time, supported through programs such as the US Environmental Protection Agency (USEPA) Section 319 Nonpoint Source Management Program. These projects bring together urban and rural people around our natural resources and give communities a voice in the protection of their water resources. In fact, the USEPA identifies partnership building as the first step in the watershed planning process (USEPA 2013). Thus, watershed planning has the opportunity to underscore the need for greater inclusivity around the protection of our water resources.

In 2018, members of the SWCS Science and Policy Committee laid out a set of conservation principals that spoke to the universal dependency on and responsibility for clean water. One of the principals stated SWCS's belief that "all

Clare Lindahl is the chief executive officer of the Soil and Water Conservation Society in Ankeny, lowa. communities should have access to safe and plentiful drinking water, or source water" (Manale et al. 2018). The committee also identified a policy implication for conservation title funding through the United States farm bill to encourage cooperation between water utilities and farmers (Manale et al. 2018). The passing of the 2018 Farm Bill did just that, with provision of US $\$ 4$ billion in funding to support partnerships between utilities and the agricultural community. American Water Works Association Chief Executive Officer David B. LaFrance called the bill "a historic moment for source water protection" that will offer an opportunity to forge new relationships to bring together urban and rural residents (LaFrance 2019).

In addition to advocating for policy support, SWCS has provided a platform for sharing the best practices for watershed planning from leading academics around the world through the Journal of Soil and Water Conservation and books like How to Build Better Agricultural Conservation Programs to Protect Water Quality: The National Institute of Food and AgricultureConservation Effects Assessment Project Experience. These publications demonstrate the ways that new technologies and tools like the Agricultural Conservation Planning Framework (ACPF) can help watershed management staff target practices for best results (McLellan et al. 2018), and they establish the importance of a monitoring program that aligns with project objectives and occurs at multiple scales (Osmond et al. 2012). They also acknowledge that watershed improvement efforts are at threat of failure if they do not take a participatory approach and "account for the needs, constraints, and practices of local people" (Smith 2013).

Indeed, it is local people who make decisions about the land, a sentiment that is expressed so well through the USDA Natural Resources Conservation Service slogan: "Helping People Help the Land." For SWCS, an international association for conservation professionals, the value of those who advise those who manage the

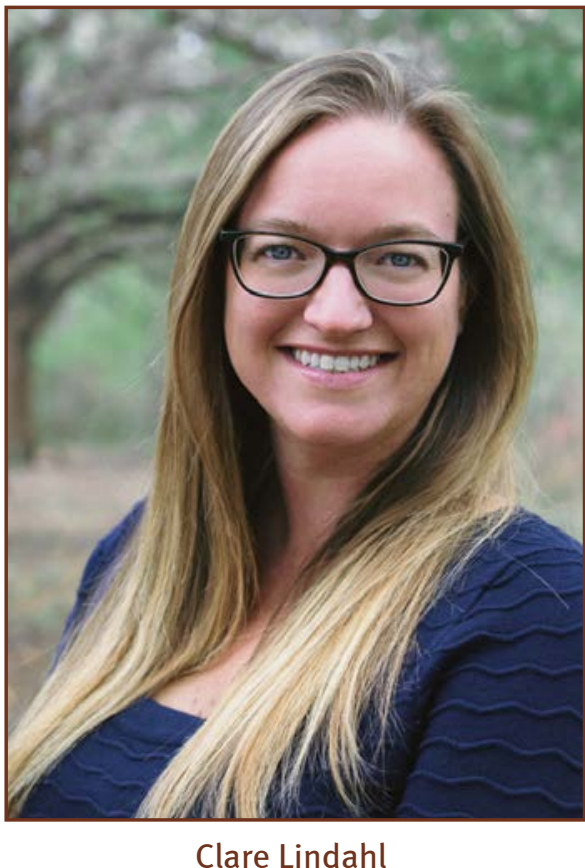

land is a main priority. SWCS has believed from the very start in the importance of the practitioner and the need for the support of conservation technical assistance. Ralph H. Musser, the first president of SWCS, said, "At the core of this great endeavor to hold onto the world's productive soil and water, will be the professional soil conservationist" (Musser 1946). Today, however, the "professional soil conservationist" has become an interdisciplinary team of professional conservationists, including watershed coordinators and managers.

Providing support and training for the staff who work on a watershed scale to bring together multiple public and private sector partners and watershed residents is crucial to the protection of our natural resources. These boots-on-the-ground conservationists design and implement watershed plans for the betterment of their local water resources and communities. They are implementing what the US Water Alliance calls a One Water approach, in which all water is managed in an "integrated, inclusive, and sustainable manner to secure a bright, prosperous future for our children, our communities, and our country" (US Water Alliance 2017). 
In December of 2018, inspired by the One Water movement, SWCS cohosted the North Central Region One Water Action Forum with the US Water Alliance, North Central Region Water Network, and Iowa Soybean Association. The forum joined a diverse set of stakeholders and topics around our world's most precious resource, water. While facilitating dialogue at one of the nine working sessions held on a variety of water-related topics, SWCS was again reminded by watershed coordinators in attendance that their ability to obtain tools, connections, and trainings will directly impact their ability to unify stakeholders and protect water resources. Watershed coordinators are asked to have many competencies, such as a technical understanding of conservation, project management, sales, and communication skills.

An answer to this training need is provided through the Iowa Watershed Academy, a series of courses held in partnership with Iowa State University Extension and Outreach and made possible by made possible by a Conservation Innovation Grant from the USDA Natural Resources Conservation Service. Through Watershed Academy workshops, SWCS continues to bring watershed coordinators the skills, networks, and tools they need in order to achieve measurable results in water quality.

In July of 2019, the Soil and Water Conservation Society (SWCS) will convene in Pittsburgh, Pennsylvania, for the 74th SWCS International Annual Conference, where we plan to continue and diversify conversation surrounding successful urban and rural collaborations, such as we've seen through watershed planning efforts. The theme of this year's event is "Bridging the Divide: Uniting Rural and Urban Landscapes for Conservation." The conference will explore new topics including watershed planning across urban and rural communities; engaging the private sector in conservation; growing urban agriculture in postindustrial landscapes; and applying green infrastructure for a more economically, ecologically, and socially sustainable environment through our newly formed partnership with the
Green Infrastructure Foundation and Green Roofs for Healthy Cities.

In 1987, the Soil Conservation Society of America became the Soil and Water Conservation Society, adding water to the name and purview while recognizing the organization's soil conservations roots. Whatever your conservation career-soil conservationist, watershed coordinator, educator, policy maker, administrator-we are all working in a watershed, and the work we do on the ground impacts the health of surface and groundwaters, shared resources upon which all of life depends.

\section{REFERENCES}

LaFrance, D.B. 2019. A call to action: How to use $\$ 4$ billion for source water protection. Journal of the American Water Works Association 111(4):7, doi:10.1002/awwa.1264.

Manale, A., A. Sharpley, C. DeLong, D. Speidel, C. Gantzer,J. Peterson, R. Martin, C. Lindahl, and N. Adusumilli. 2018. Principles and policies for soil and water conservation. Journal of Soil and Water Conservation 73(4):96A-99A, doi:10.2489/ jswc.73.4.96A.

McLellan, E.L., Keith E. Schilling, C.F. Wolter, M.D. Tomer, S.A. Porter, J.A. Magner, D.R. Smith, and L.S. Prokopy. 2018. Right practice, right place: A conservation planning toolbox for meeting water quality goals in the Corn Belt. Journal of Soil and Water Conservation. 73(2):29A-34A, doi:10.2489/jswc.73.2.29A.

Musser, R.H. 1946. Why another society? Journal of Soil and Water Conservation 1(1):3-4.

Osmond, D.L., D.W. Meals, D.LK. Hoag, and M. Arabi, eds. 2012. How to Build Better Agricultural Conservation Programs to Protect Water Quality: The National Institute of Food and Agriculture-Conservation Effects Assessment Project Experience. Ankeny, IA: Soil and Water Conservation Society.

Smith, K.W. 2013. Watershed management networks and the necessary role of collaboration. Journal of Soil and Water Conservation 68(2):53A-54A, doil:10.2489/jswc.68.2.53A.

USEPA (Environmental Protection Agency). 2013. A Quick Guide to Developing Watershed Plans to Restore and Protect OurWaters. Washington, DC: US Environmental Protection Agency. https:// www.epa.gov/sites/production/files/2015-12/ documents/watershed_mgmnt_quick_guide.pdf.

US Water Alliance. 2017. One Water for America Policy Framework: Executive Summary. Washington, DC: US Water Alliance. http:// uswateralliance.org/sites/uswateralliance. org/files/publications/One\%20Water\%20 for $\% 20$ America\%20Policy\%20Framework $\% 20$ Executive\%20Summary.pdf. 